\title{
From the Guest Editors
}

\section{An Overview of Classroom Composition Research on Social-Emotional Outcomes: Introduction to the Special Issue}

\begin{abstract}
Classroom composition research on social-emotional outcomes (CCRSO) aims to systematically explore how characteristics of classmates are related to the socialemotional outcomes of children and adolescents. In this introduction to the special issue, we first provide an overview of the scientific roots of CCRSO. We then develop a conceptualization of research areas typically of interest in CCRSO, which comprises 4 different fields of inquiry. Based on this, an overview on exemplary studies in these areas of research is given. Finally, we provide an introduction to methodological approaches and current challenges of CCRSO. We end with a brief discussion on potential future research directions.
\end{abstract}

Keywords: classroom composition; social-emotional functioning; peer influence; school effectiveness

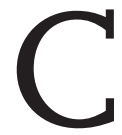

hildren and adolescents spend a large part of their day at school. Besides offering academic learning opportunities, school is a major place for social interaction and building relationships with peers (Crosnoe, 2011). During classes, students can discuss and collaborate with their classmates on subject matters and observe each other's interactions with peers and teachers. Breaks then provide possibilities to meet with friends from class in an informal way. Even after school, contact with classmates often continues on the school bus as well as when meeting each other in spare time and when keeping in touch at home via social media. It can thus be expected that classmates play an important role for students' personal development. Classroom composition research on social-emotional outcomes (CCRSO) deals with exactly this issue: The aim is to systematically explore how characteristics of the classroom composition, meaning the characteristics of students attending a specific classroom, are related to the social-emotional outcomes of individual children and adolescents.

Social-emotional outcomes here are considered as an umbrella term that encompasses inter- and intrapersonal competences and processes that are essential for functioning in social 
interactions and relationships (for overviews, see e.g., Ciarrochi, Scott, Deane, \& Heaven, 2003; Denham, Wyatt, Bassett, Echeverria, \& Knox, 2009; Weissberg, Durlak, Domitrovich, \& Gullotta, 2015). Comprising both positive and negative aspects, social-emotional functioning conceptually includes social competent behaviors (e.g., building enduring relationships, social awareness), accurate emotional management (e.g., express emotions in socially appropriate ways), as well as troublesome externalizing (e.g., aggression, delinquency) and internalizing behaviors (e.g., anxiety, social withdrawal). Specific cognitions such as attitudes toward social behaviors or self-concept can be viewed as being closely connected to socialemotional functioning (e.g., Blakely-McClure \& Ostrov, 2016; Vogl \& Preckel, 2014).

Most scientists agree that healthy social-emotional development during childhood and adolescence is closely related to quality of life and positive development into adulthood. In turn, problems in social-emotional functioning are viewed as being predictive of mental health issues and disadvantageous conditions later in life (for overviews, see e.g., Kessler et al., 2010; Masten \& Coatsworth, 1998; Rutter, Kim-Cohen, \& Maughan, 2006). It is thus important to understand the predictors of social-emotional outcomes and their underlying mechanisms of influence.

The investigation of factors that impact social-emotional development has produced a variety of both individual and contextual variables. While there are important genetic and neuropsychological predispositions (Raine, 2008), the focus of CCRSO is on questions related to contextual effects. Investigation into such factors has a long history in the social sciences. For example, countless studies give evidence of the crucial role that parent and neighborhood characteristics play for the social-emotional development of children and adolescents (e.g., Brooks-Gunn, Duncan, \& Aber, 2000; Morris, Silk, Steinberg, Myers, \& Robinson, 2007). In the same vein, peer context and school environment were identified as important sources of influence (Gottfredson, 2001; Warr, 2002). In our view, the two research lines concerned with the investigation of these factors-peer influence research and school effectiveness research-form the major scientific avenues that lead to current CCRSO. In the following, we will thus briefly describe these lines of research before giving an overview of current CCRSO.

\section{SCIENTIFIC ROOTS OF CCRSO}

Historical lines underlying current research approaches can be read, interpreted, and arranged differently. In this sense, our understanding of the scientific traditions contributing to the development of CCRSO may be fragmented and surely is also subject to individual academic backgrounds. Nevertheless, we consider it a fruitful endeavor to think about how different research lines historically existed in parallel and now appear to form a common perspective in many researchers' work.

\section{Peer Influence Research}

Clearly, one major root of CCRSO is represented by theories and studies on peer influence. This type of research is typically interested in the interactions, relationships, and influence processes between peers. The question of which role the peers play in children's and adolescents' development of cognition, skills, identity, and social-emotional functioning began being systematically investigated in the early decades of the 20th century. Peer influence research since then has been a very active field of study across different social science disciplines 
(for overviews, see, e.g., Prinstein \& Dodge, 2008; Rubin, Bukowski, \& Laursen, 2009). Taking Sutherland's differential association theory from 1939 (Gaylord \& Galliher, 1988) and its further developments (Akers, 2009; Burgess \& Akers, 1966) as an example from criminological research, a large number of studies showed that the level of delinquency among peers is one of the strongest predictors of adolescents' involvement in such behavior (Akers \& Jensen, 2006). Important steps then were taken when realizing that selection into peer groups based on homophily and socialization within these groups are not mutually exclusive but appear to be closely related reciprocal processes (Warr, 2002). Other studies showed that peers not only exert influence on externalizing but also on internalizing and social competent behaviors of children and adolescents (e.g., Barry \& Wentzel, 2006; Hogue \& Steinberg, 1995; Prinstein, 2007). Furthermore, substantial progress was made in understanding the psychological mechanisms underlying peer influence. Important processes such as opportunities provided by the peers, social modeling, social reinforcement, social comparison, emotional contagion, and others were identified (for overviews, see e.g., Brown, Bakken, Ameringer, \& Mahon, 2008; Dishion \& Tipsord, 2011; Hartup, 2009; Warr, 2002).

From early on, the role of social status was also recognized as a crucial factor in the context of peer relationships and social-emotional outcomes. Typically, it is differentiated between what Cillessen and Marks (2011, p. 28) in an overview on the topic called the "traditional sociometric status categories": popular (traditionally assessed as "who do you like most"), rejected, neglected, controversial, and average types of social status. However, the way popularity is understood and measured has changed since the early studies. What was before termed popularity (being liked) is now often termed likeability because there were important differences found between "being liked" and "being popular." Although likeability relates primarily to being socially accepted, (perceived) popularity (typically assessed as "who is most popular") relates to a person`s visibility, prestige, and social impact (Cillessen \& Marks, 2011). There are now many studies showing that individuals with differing social status positions substantially differ in their behavioral profiles and roles in peer influence processes (for an overview, see Asher \& McDonald, 2009).

Interestingly, many peer influence studies are conducted in schools because it is widely acknowledged that peer relationships often are formed in this context. The primary interest of these studies is often on examining self-selected friendships and cliques (e.g., the influence of the friends' characteristics on individual students). These peer groups can relate to students from the same school or classroom (e.g., Vitaro, Brendgen, \& Tremblay, 2000), but they may also include social networks from outside of school (e.g., Kiesner, Poulin, \& Nicotra, 2003). This primary focus of peer influence research on self-selected peer groups contrasts with CCRSO in which the main interest is on non-self-selected peers, namely, all classmates from a classroom (i.e., the influence of the characteristics of all classmates on individual students).

Why is it important to differentiate between self-selected and non-self-selected peer groups? Classrooms, in contrast to cliques and friendship groups, are involuntary peer groups (Juvonen \& Galvàn, 2008). This means that children and adolescents usually cannot decide themselves which classroom in a schoolhouse they attend. Internationally, this is the case for most preschool, kindergarten, and primary school classrooms. Regarding middle and secondary schools, there is more variation; while in some countries, students are unambiguously assigned to specific academic tracks and classrooms, in other countries, students can at least partly choose. However, even when being able to decide for a classroom with some former friends to meet there, students in their classroom find themselves surrounded by 
any peer attending this class. The group of all classmates thus is substantially different from personal friends, with whom students share social bonds and similarity in behaviors and attitudes. Also, friendship groups are often smaller in size than whole classrooms. It is thus not evident that children and adolescents are influenced by involuntarily assigned classmates to the same extent and by the same underlying processes as by their friends. Furthermore, it should be noted that when considering the influence of the whole classroom composition on an individual student, the aspect of peer selection falls away in the social influence process (at least in many school systems). This led researchers suggest that studies examining classroom composition effects in school systems with clear classroom assignments and self-contained classrooms allow to identify "pure" peer socialization effects (e.g., Araos, Cea, Fernandez, \& Valenzuela, 2014; Busching \& Krahé, 2015).

\section{School Effectiveness Research}

While peer influence research contributed valuable theories and empirical findings on the way that children and adolescents influence each other, a second root of CCRSO lies in school effectiveness research. This type of research can be traced back to the seminal works of Coleman et al. (1966), Jencks et al. (1972), and Rutter, Maughan, Mortimore, and Ouston (1979). School effectiveness research primarily investigates the influence of factors related to educational systems and schools on students' academic development (for overviews, see, e.g., Chapman et al., 2012; Teddlie \& Reynolds, 2000). Starting from the question of whether "schools make a difference or not," a major strand of school effectiveness research aims at explaining school and classroom variance in students' achievement (see also Scheerens \& Creemers, 1989). In line with this, there is a long-standing interest toward the effects of classroom composition.

Over the last 40 years, a vast amount of studies have been conducted in which students' achievement was predicted by school and classroom characteristics, such as the student composition in terms of ethnic and socioeconomic background (e.g., Alexander \& Eckland, 1975; Burns \& Mason, 2002; Dreeben \& Barr, 1988; Hornstra, van der Veen, Peetsma, \& Volman, 2015; for overviews, see Dumont, Neumann, Maaz, \& Trautwein, 2013; van Ewijk \& Sleegers, 2010a, 2010b). In this context, conceptual and methodological issues of compositional research have been intensively debated (e.g., Erbring \& Young, 1979; Hallinan, 1988; Harker \& Tymms, 2004; Raudenbush \& Bryk, 1986). Furthermore, a strong line of research focused on the impact of ability grouping, examining how classmates' achievement influences individual students' academic and motivational development (for overviews, see, e.g., Chmielewski, Dumont, \& Trautwein, 2013; Gamoran, 2010; Hanushek \& Woessmann, 2006). Less numerable, some studies also investigated how educational stratification affects students' schoolrelated attitudes and behaviors (e.g., Abraham, 1989; Berends, 1995; Hargreaves, 1967; Van Houtte, 2006).

Although the main interest of school effectiveness research typically is on students' academic outcomes, CCRSO benefits from the extensive conceptual and methodological knowledge provided by this type of studies. For example, school effectiveness research provides important insights on the role that factors such as academic tracking, curricula, and teachers' instructional styles play in students' development (Gamoran, 1987; Kerckhoff, 2001; Oakes, 1987; Van Houtte, 2004). Such information is not only relevant for understanding students' academic progress but also their social life at school. 
As an example of the complex relations between individual, peer, and school characteristics, one may consider the process of assignment of students to secondary school classrooms and following influence processes. Classroom composition the secondary school level often is predetermined by the assignment of individual students to different academic tracks; this process is not only related to students' achievement but is also linked with their background characteristics and school organizational factors (Gamoran, 2010; Maaz, Trautwein, Lüdtke, \& Baumert, 2008). Attending track-specific classrooms, students meet specific curricula and peer contexts (e.g., in terms of the level of problem behaviors among the classmates), which may have an impact on their social-emotional development (Müller \& Hofmann, 2014; Van Houtte, 2006; Van Houtte \& Stevens, 2008). Based on the premise that compositional effects operate through different levels, it can be assumed that school, classroom and individual factors influence each other (Wilkinson, Parr, Fung, Hattie, \& Townsend, 2002). For example, teachers may adapt their teaching style to the level of problem behavior in a classroom, which in turn influences individual students' behavior (see also Buyse, Verschueren, Doumen, Van Damme, \& Maes, 2008; Pas, Cash, O’Brennan, Debnam, $\&$ Bradshaw, 2015). Furthermore, interactions can be expected such that the amount of peer influence in the classroom depends on the teacher's behavior. By organizing seating positions, composing working groups, and establishing social rules, teachers contribute to the ways that peers interact with each other. These peer interactions in turn can have a direct impact on students' social-emotional outcomes (see also Farmer, Lines, \& Hamm, 2011; van den Berg, Segers, \& Cillessen, 2012).

Having presented peer influence research and school effectiveness research as two distinct roots of CCRSO, it should be emphasized that the boundaries between them are actually oftentimes blurred. As an example, an exciting line of peer influence research explicitly deals with the role of institutions in prestructuring peer influence processes (for an overview, see Dodge, Dishion, \& Lansford, 2006). Here, different institutional settings that bring together adolescents with deviant behaviors (e.g., mental health care, young offenders institutions, alternative schools) are critically reflected in the light of findings on peer influence mechanisms and potentially iatrogenic effects. In this regard, Dishion and Piehler (2009) stated the provocative hypothesis that certain settings designed to benefit youth can be "deviant by design" because the aggregation of deviant adolescents contents a specifically high risk of peer contagion effects (for a school-related discussion, see Müller, 2010; Reinke \& Walker, 2006). The conceptual approach of such types of peer influence research actually has many similarities to questions dealt with in school effectiveness research, and there may be many examples the other way around. In our view, the goal is thus not to unambiguously distinguish between peer influence and school effectiveness research; instead, the knowledge about the specific strengths of both of these perspectives may significantly help to move forward the relatively new field of CCRSO.

\section{RESEARCH AREAS OF CCRSO AND EXEMPLARY FINDINGS}

CCRSO aims to answer different types of research questions. In an attempt to provide an overview, we identified four typical areas of study (Table 1). These are all characterized by investigating individual social-emotional outcomes as the criterion of interest (there may be more areas of CCRSO when not including this limitation). Studies relating to Areas $A, B$, and $C$ all focus on the process of influence from characteristics of the classroom composition on 
TABLE 1. Current Areas of Inquiry in Classroom Composition Research on Social-Emotional Outcomes (CCRSO) Examining Individual Social-Emotional Outcomes as Criterion

\begin{tabular}{|c|c|c|c|}
\hline A & B & $\mathrm{C}$ & $\mathrm{D}$ \\
\hline $\begin{array}{l}\text { Main effects of } \\
\text { classroom compo- } \\
\text { sition on individual } \\
\text { social-emotional } \\
\text { outcomes }\end{array}$ & $\begin{array}{l}\text { Mediators of class- } \\
\text { room composition } \\
\text { effects on individual } \\
\text { social-emotional } \\
\text { outcomes }\end{array}$ & $\begin{array}{l}\text { Moderators of class- } \\
\text { room composition } \\
\text { effects on individ- } \\
\text { ual social-emotional } \\
\text { outcomes }\end{array}$ & $\begin{array}{l}\text { Classroom composition } \\
\text { as moderator of other } \\
\text { influences on indi- } \\
\text { vidual social-emotional } \\
\text { outcomes }\end{array}$ \\
\hline
\end{tabular}

individual social-emotional outcomes. These studies can further be divided in those in which the constructs are the same between the classroom predictor and the individual outcome (e.g., mean aggression in classroom predicts individual aggression) and those in which the classroom predictor and individual outcome differ (e.g., gender proportion in class predicts individual aggression). To not overburden this article, in the following overview on exemplary studies in research Areas $A$ to $C$, our primary focus will be on those which investigated the same construct on the classroom and the individual level, but we will also make references to other studies. Research relating to Area $D$ considers classroom composition as a moderating factor of other influences on individual social-emotional outcomes (e.g., social status is predicted by individual aggressive behavior, and this relationship is moderated by average aggression in the classroom). In the following text, we will provide more detail on this categorization and refer to exemplary findings and some perspectives on the practical implications that each field of research may hold.

\section{Main Effects of Classroom Composition on Individual Social-Emotional Outcomes}

This area of research concerns one of the most fundamental questions of CCRSO, namely, whether characteristics of classmates influence students' individual social-emotional outcomes. Based on peer influence theories and empirical studies on self-selected peer groups described before, it can be expected that classmates influence each other in their socialemotional development. For example, it could be hypothesized that students with a similar level of aggressive behavior at the beginning of a school year will develop more aggressive behavior in a classroom with high mean levels of aggression among the classmates than in a classroom with low aggression levels. This in fact is what Kellam, Ling, Merisca, Brown, and Ialongo (1998), in their pioneering study found among boys who were followed from Grade 1 to Grade 6. Today, many studies replicated this result across different domains of social-emotional functioning and including students from preschool, kindergarten, primary, and secondary school classrooms (Barth, Dunlap, Dane, Lochman, \& Wells, 2004; Henry et al., 2000; Kuppens, Grietens, Onghena, Michiels, \& Subramanian, 2008; Mercer, McMillen, \& DeRosier, 2009; Müller, Hofmann, Fleischli, \& Studer, 2016a; 2016b; Thomas \& Bierman, 2006; Thomas, Bierman, \& Powers, 2011; Warren, Schoppelrey, Moberg, \& McDonald, 2005). However, there are also a few studies that did not find such classroom effects. For example, Henry et al. (2000), in parts of their analyses, did not find evidence that classroom aggression affects individual aggressive behavior (see also e.g., Bosse, Gerritsen, \& Klein, 2010). 
Other studies in research Area $A$ did not predict individual social-emotional outcomes by the same characteristics of the classmates but used other classroom variables as predictors (e.g., Araos et al., 2014; Busching \& Krahé, 2015; Henry et al., 2000; Hoglund \& Leadbeater, 2004; Mercer et al., 2009; Stearns, Dodge, \& Nicholson, 2008; Werthamer-Larsson, Kellam, \& Wheeler, 1991). As examples, Hoglund and Leadbeater (2004) found that classroom levels of prosocial behaviors and victimization predicted students' individual social competence, and Werthamer-Larsson et al. (1991) reported that attending low-achieving and poor-behaving first-grade classrooms predicted increased shy behavior of students. Effects on individual social-emotional outcomes were also found regarding variables such as proportions of boys and girls (e.g., Brutsaert \& Van Houtte, 2004) or students from different ethnic groups in schools and in classrooms (e.g., Demanet \& Van Houtte, 2011; Jackson, Barth, Powell, \& Lochman, 2006).

Having found effects of classmates' characteristics on individual social-emotional outcomes, an important question is how specific these effects are. Generally, many studies showed that classroom composition effects remained significant when controlling for other predictors of the criterion of interest. These control variables included, for example, child characteristics, family background, classroom climate, and academic track (e.g., Müller et al., 2016a; Powers \& Bierman, 2013; Thomas et al., 2011; Werthamer-Larsson et al., 1991). Less research was conducted on the question of how specific the effect of classmates is in light of the impact of other peer groups. Findings from Müller et al. (2016a) suggest that when statistically controlling for the influence of friends from outside the classroom, the effect of classroom composition on different types of antisocial behaviors remains significant. Because this was the case even for behaviors typically exhibited outside of school (e.g., delinquent acts), it can be expected that classmates influence each other not only in the school setting but also during spare time.

Some studies also investigated how the impacts of all classmates and different subgroups of peers within the classroom relate to each other in predicting individual social-emotional outcomes. For example, Powers and Bierman (2013) reported that both the aggression level among all classmates and aggression among students' personal friends in class made a unique contribution to child aggressive behavior. Generally in line with this, Müller et al. (2016b) found an influence of perceived aggressive and disruptive behavior among all classmates, among socially dominant students, and among personal friends in class on students' individual behavior. When the effects of these groups were compared, no significant differences were identified. Regarding gender, however, Stearns and colleagues (2008) found that elementary school boys' and girls' authority-acceptance problems were more influenced by the level of such behavior among the same gender peers in the classroom. In addition, Busching and Krahé (2015) reported that aggression-related normative beliefs among female students in class were better predictors of individual aggressive behavior than male beliefs.

Research dealing with questions of research Area $A$ have the potential to inform school practice on the effects of different grouping procedures. These relate, for example, to the issue of how academic tracking or special needs schooling should be organized because classrooms often differ in students' social-emotional difficulties along different school types. At the school level, results on composition effects may help principals in planning the composition of classrooms. At the classroom level, teachers may benefit from findings in their decisions on who should advisably work together in student groups and which constellations may turn out as risking negative peer influence processes. 


\section{Mediators of Classroom Composition Effects on Individual Social-Emotional Outcomes}

Besides investigating the main effects of classroom composition on individual social-emotional development, it is an important question by which exact mechanisms classroom-level characteristics are transmitted to individual students. Statistically, this relates to examining which factors mediate the effect of composition on individual outcomes.

Generally, many studies in CCRSO rely on a theoretical framework, which suggests that in groups, there exist different kinds of social norms (Cialdini, Kallgren, \& Reno, 1991; Deutsch \& Gerard, 1955). Accordingly, among classmates, descriptive norms (norms of what "is"; i.e., mean level of aggressive behaviors) and injunctive norms (norms of what "ought to be"; i.e., mean level of attitudes toward aggression) can be expected (e.g., Henry et al., 2000; Mercer et al., 2009). The transmission of these peer norms on individual student behaviors can be expected to include different mechanisms. For example, norms toward aggression may be communicated via verbal and nonverbal reinforcement of deviant utterances of peers (“deviancy training"; Dishion \& Tipsord, 2011). Others may involve social modeling via peer observation (Akers, 2009; Bandura, 1977). The importance of such processes in peer influence research was often established using well-designed experiments in which peers directly interact with each other (e.g., Dishion, Spracklen, Andrews, \& Patterson, 1996). In CCRSO, however, it can be challenging to examine these processes because the larger classroom is of interest and most studies rely on questionnaire information.

One attempt to nevertheless approach this issue may be seen in a study that examined the effect of classroom composition regarding disruptive behavior (i.e., mean level of disruptive behavior in class) on students' future individual disruptive behavior (Müller, Hofmann, Fleischli, \& Studer, 2015). Here, the composition effect was mediated by the individual student's observation of disruptive behavior among the classmates (i.e., individually perceived proportion of classmates exhibiting disruptive behavior). This effect may indicate social modeling processes in classrooms. Henry et al. (2000), in contrast, stressed the importance of students' individual attitudes in these processes. They found that injunctive norms influenced aggressive behavior by changing personal normative beliefs about aggression. The authors concluded that children do not merely imitate the behavior of their classmates but that behavioral choices are mediated by beliefs about the morality of aggressive behavior. In addition, findings from a study by Powers and Bierman (2013) showed that aggressive classroom contexts have an indirect effect on individual aggression by changing students' proximal peer experiences, such as their social status and friendship networks in class. Still, other studies suggest that classroom composition could exert influence via teachers' instructional styles. For example, Skinner and Belmont (1993) observed that behaviorally disengaged students often receive teacher response that can further undermine their motivation. It could thus be expected that classroom composition effects on problematic individual behavior are mediated by a less advantageous teaching style (see also Barth et al., 2004; Buyse et al., 2008; Pas et al., 2015; Thomas et al., 2011; Van Houtte, 2004). However, to our knowledge, such a mediation effect has not yet been directly tested in CCRSO.

Studies investigating research questions in Area $B$ can provide valuable insights for school practice because knowing the mechanisms of how classroom composition exerts influence may allow to counteract against unfavorable developments. For example, if social modeling turns out to be a major mediator of classroom composition effects on students' aggressive behavior, an important goal may be to reduce opportunities to observe such behavior in the 
classroom and to actively provide prosocial modeling. If aggressive classroom behavior instead would turn out to be mediated by, for instance, aversive teacher behavior, this finding may help teachers to be more aware of such situations and to actively adapt their instruction.

\section{Moderators of Classroom Composition Effects on Individual Social-Emotional Outcomes}

Another area of CCRSO considers the question of which students under which conditions are specifically susceptible to the classmates' influence. Although there are a lot of studies on the moderators of the impact of self-selected peer groups (for overviews, see Müller \& Minger, 2013; Prinstein, 2007), studies specifically focusing on classroom composition effects on social-emotional outcomes are still less numerable. Taking the topic of antisocial behavior as an example, existing studies suggest that the influence of classmates' levels of antisocial behaviors depends on different individual and contextual factors. For instance, in some studies, individuals were more susceptible to the effects of antisocial classroom composition when they were of male gender, exhibited higher initial levels of antisocial behavior, scored higher on impulsivity, risk tolerance, self-worth problems, social dominance, and cool appearance. Furthermore, students who experienced more unstructured spare time, less parental supervision, and who attended classrooms in which antisocial behavior levels were more homogeneously distributed experienced more influence from their classmates (e.g., Kellam et al., 1998; Müller, Hofmann, \& Arm, in press; Müller et al., 2016a; Warren et al., 2005). However, some of the reported effects were not found in other studies (Kuppens et al., 2008; Powers \& Bierman, 2013) which may be related to different age groups and behavioral domains considered. Furthermore, it is still less clear how different moderators of classroom composition effects relate to each other and how specific they are. For example, in a recent paper examining 10 potential moderating factors of classroom composition on delinquency development, only male gender remained a significant moderating factor when several moderators were considered within one model (Müller et al., in press).

Findings on research investigating Area $C$ may help teachers to better recognize students who are specifically susceptible to their classmates' influence and provide them individual support. In the same vein, if issues such as students' impulsiveness or school-related factors should turn out to indeed moderate classroom composition effects, such knowledge can help to more systematically counteract negative influence processes. For example, it could be that inhibition trainings not only help students to generally better deal with high impulsiveness but they may also reduce their susceptibility to negative peer influence processes. However, the effectiveness of interventions aiming at reducing negative peer influence in class via intervening on the moderating factors, to our knowledge, has not yet been systematically investigated.

\section{Classroom Composition as Moderator of Other Influences on Individual Social-Emotional Outcomes}

Another line of CCRSO focuses on classroom composition as a social reference for the development of students' social-emotional outcomes. Conceptually, classroom composition characteristics (e.g., mean level of aggression in class) here are considered as having a moderating role on the relationship between an individual factor (e.g., student's aggression) and individual social-emotional outcome (e.g., being rejected in class). Questions of this type can be analyzed using interaction effects but also various other statistical approaches (see e.g., 
MacKinnon, 2008). Hence, this category does not primarily relate to a specific type of statistical analysis but to the general idea that the effects of individual-level variables and effects of classroom-level factors depend on each other in predicting individual social-emotional outcomes.

Some studies in research Area $D$ investigated how students' social status relates to both individual and classroom characteristics (Chang, 2004; Jackson, Cappella, \& Neal, 2015; Jonkmann, Trautwein, \& Lüdtke, 2009; Stormshak, Bierman, Bruschi, Dodge, \& Coie, 1999; Wright, Giammarino, \& Parad, 1986). Stormshak et al. (1999), for example, found that aggressive students were less liked in nonaggressive classroom contexts, while there was no such effect in classrooms with a high level of aggression among classmates. This observation is in line with a person-group similarity model predicting that the acceptability of social behaviors will vary as a function of peer group norms. In contrast, regarding other domains, the authors found that individual inattentive/hyperactive (in a negative direction) and prosocial behaviors (in a positive direction) affected social status independently of the characteristics of classmates. Stormshak et al. interpreted this finding in the framework of a social skill model, suggesting that certain behavioral skill deficiencies reduce and behavioral competencies enhance peer preference irrespectively of the group characteristics. Relating these insights to other social-emotional outcomes, Bellmore, Witkow, Graham, and Juvonen (2004) found that the association between victimization and anxiety was stronger in classrooms with low social disorder.

Although not directly comparable to the aforementioned examples, a well-established classroom compositional effect that is important to mention in the context of research in Area $D$ is the big-fish-little-pond effect (BFLPE; Marsh, 1987; for an overview, see e.g., Seaton, Marsh, $\&$ Craven, 2009). The BFLPE relates to the question of why students with comparable academic achievement differ in their perceptions of their academic abilities along different schools and classrooms. The BFLPE posits a negative frame-of-reference effect: The group-average achievement in the classroom has a negative effect on individual academic self-concept beyond the positive effect of individual achievement on self-concept. Several studies confirmed the BFLPE (e.g., Huguet et al., 2009; Marsh, Kong, \& Hau, 2000; Zurbriggen, 2016).

In connection with the BFLPE, the basking-in-reflected-glory effect (BIRGE; Cialdini et al., 1976) has been frequently mentioned. The BIRGE (in some studies, also referred to as assimilation effect) states that being in a class or school with a high social status (e.g., average socioeconomic status, self-perceived status) or in a high-ability track is likely to foster a sense of pride, and thus, to enhance students' academic self-concept (e.g., Marsh et al., 2000; Trautwein, Lüdtke, Marsh, \& Nagy, 2009). However, this positive contextual effect seems to be much less pronounced than the negative BFLPE.

Research in field $D$ is helpful to better understand how individual characteristics and the classroom context together impact students' social-emotional outcomes. As such, findings from this research can help to identify students specifically at risk for rejection or low self-concept in specific classroom settings. Furthermore, existing results suggest that when trying to ameliorate the situation of students (e.g., their social status), interventions may aim not only at the individual himself but also at the classroom as a crucial context of individual development.

In conclusion, this brief description of subjects investigated in CCRSO shows the specificity of this type of research in terms of a focus on classrooms and students' social-emotional development. Furthermore, the complexity of potential relationships between individual, 
classroom, and school characteristics became evident. In an attempt to most adequately take into account this complexity, CCRSO is necessarily also concerned with many methodological questions.

\section{METHODOLOGICAL APPROACHES AND CHALLENGES OF CCRSO}

For more than 40 years, methodological issues related to student composition effects have been a topic of debate in several disciplines of social science (e.g., Bliese, 2000; Cronbach, 1976; Erbring \& Young, 1979; Little, Bovaird, \& Card, 2007; Lüdtke, Marsh, Robitzsch, \& Trautwein, 2011; Manski, 1993; Raudenbush \& Bryk, 1986). These discussions on different ways of operationalization and statistical approach have contributed considerably to an adequate analysis and understanding of classroom composition influences. Although a comprehensive overview is far beyond the scope of this article, in the following text, we give a short introduction into this topic of great importance for CCRSO.

\section{Types of Classroom-Level Concepts}

When trying to disentangle different concepts related to classroom characteristics, it is useful to distinguish between classroom-level constructs that can be measured directly at the group level (e.g., class size, teaching subject) and those that are generated by aggregating individual variables (Lüdtke et al., 2008). Regarding the latter type, it is necessary to further differentiate between formative and reflective aggregation.

Formative aggregation of individual-level variables generates a classroom-level construct that is not evident on the individual level (e.g., gender proportion, class-average aggression, class-average achievement). In other words, the construct is an aggregate of individual students' "characteristics that are specific to each person in the class" (Marsh et al., 2012, p. 109). Therefore, the variance existing between students (e.g., in terms of gender, aggression, or achievement) represents an important classroom characteristic.

In contrast, reflective aggregation of individual-level variables is used to measure grouplevel constructs where the scores or responses of students of the same class can be thought of as interchangeable. More specifically, every student of a class may be asked to rate a common characteristic of the group or classroom that is relevant for all of them (e.g., social cohesion of the class, perception of teacher's instructional style, classroom climate). A lack of agreement among students within the same class is thus considered as a source of unreliability of the reflective classroom-level construct. It should be noted, however, that pure reflective aggregated measures — with absolute agreement among students-are extremely rare (Bliese, 2000; Lüdtke et al., 2011).

Because questions investigated in CCRSO usually focus on the effects of student composition of classrooms, typically formative aggregation of individual variables is used to characterize classroom characteristics. Nevertheless, researchers may also be interested in classroom-level constructs that are based on reflective aggregation. For example, it could be examined whether teachers' instructional style (e.g., reflective aggregation of students' perceptions of their teacher) moderates the relationship between classroom descriptive norms regarding aggression (e.g., formative aggregation of students' self-reported aggressive behaviors) and students' individual aggressive behavior. In the end, the choice of individual and classroom-level variables and their potential aggregation process critically depends on the theoretical rationale of a study. 


\section{Analyzing Effects of Classroom Means}

When analyzing classroom constructs based on aggregates of students' characteristics, a major challenge is to determine how to deal with the fact that an individual student forms part of the classroom whose characteristics are expected to influence this student's characteristics (for in-depth discussions, see e.g., Castellano, Rabe-Hesketh, \& Skrondal, 2014; Manski, 1993; Snijders \& Bosker, 2012). In dealing with this issue, researchers in CCRSO typically decide to "control" for the individual's characteristic in some way (to put it simply) when predicting an individual outcome by a classroom characteristic. Different approaches can be found in the literature (for an overview related to peer influence research, see Kindermann \& Gest, 2009).

For example, in many studies related to CCRSO, researchers decided to not include the individual value in the class average when computing a classroom construct so that the effect of an individual "surrounding" peer environment was measured (Barth et al., 2004; Henry et al., 2000; Hoglund \& Leadbeater, 2004). Henry et al. (2000), for instance, determined classroom descriptive norms using the mean of students' individual aggression scores, excluding the participant, to predict individual change in aggression. In other studies, classroom averages of students' characteristics were used to predict individual outcomes after statistically controlling for the same individual characteristic that was measured on the classroom level (e.g., Müller et al., 2016a; Thomas et al., 2011). As an example, researchers may decide to predict students' individual aggression at a second measurement occasion by classroom aggression and students' individual aggression at the first measurement occasion. To reduce problems of collinearity between the individual characteristic and the compositional characteristic (aggregated individual data), several authors proposed to center variables (e.g., Algina \& Swaminathan, 2011; Enders \& Tofighi, 2007; Hox, 2010). In general, the decision between grand-mean (i.e., individual difference from the overall mean) or group-mean (i.e., individual difference from the corresponding group mean) centering should be based on content considerations and on the aim of the analyses (Lüdtke, Robitzsch, Trauwein, \& Kunter, 2009; Paccagnella, 2006). Group-mean centering is often recommended in the case of "within-group effects," such as the "frog-pond" effect (Davis, 1966) or the aforementioned BFLPE. Subsequently, to estimate the appropriate effect of student composition, the individual effect has to be subtracted from the group effect to disentangle the conflation of both effects (e.g., Hox, 2010; Marsh et al., 2012).

\section{Extensions and Alternatives to Using Classroom Means}

Besides reflection on how to best analyze effects of classroom means, there appears to be a growing discontent with only considering the classroom averages in predicting socialemotional outcomes (e.g., Yudron, Jones, \& Raver, 2014). One reason for this is that students' social-emotional characteristics are usually not homogeneous in classrooms (e.g., 15 students show almost no aggressive behavior, and 5 students show a lot of aggressive behavior), and classrooms typically differ in terms of their heterogeneity. In this situation, classroom means represent an important but limited aspect of the distribution of individual features within classrooms. As a consequence, in more and more studies, the effects of further distributional variables have been investigated (e.g., Jonkmann et al., 2009; Müller et al., 2016a; Yudron et al., 2014). For example, Yudron and colleagues (2014) predicted social-emotional outcomes by several measures of classroom externalizing behaviors. They found that classroom means, standard deviations around the mean, the skew, and the proportion of children that scored 
above the whole sample 75th percentile in externalizing behavior explained distinct aspects of children's social-emotional outcomes. The authors concluded, among others, that theory and substantive concerns need to inform research which kind of summary information on the classroom level is most appropriate to answer the specific study questions at hand.

Another recent approach that takes the potential relevance of different distributional measures characterizing group composition systematically into account is the so-called group actor-partner interdependence model (Garcia, Meagher, \& Kenny, 2015; Kenny \& Garcia, 2012). For example, for an individual outcome with gender as the group composition variable, Kenny and Garcia (2012) proposed to include in the model the gender of the individual actor, gender of the other group members, actor similarity in gender to the others in the group, and the others' similarity in gender.

A further alternative completely abstaining from classroom means or proportion scores is proposed in the norm-salience concept (Henry et al., 2000; Rambaran, Dijkstra, \& Stark, 2013). Here, the correlation between social status and certain behaviors of interest within a classroom is considered and used in the statistical analyses. For example, in a classroom where aggression and popularity are highly correlated, it can be expected that aggression is rather normative because it is related to increased social status. In a conceptually related approach, Jackson et al. (2015) suggested to use classroom means adjusted for students' relative social network position within the classroom. This concept is based on the argument that the behavior of more central individuals in a classroom weighs more in defining the descriptive norms than the behavior of less central students. Using social networks analyses, the authors determined alter-based centrality measures of students and multiplied them with their aggression scores. These scores were then aggregated within each classroom to create "weighted" classroom aggression norms.

All of these procedures in our view provide interesting perspectives and may generate new insights into social processes in the classroom. Still, future studies need to further establish advantages and potential drawbacks of these new approaches in comparison to the use of the more "classic" classroom aggregates.

\section{Challenges Related to Data Characteristics}

Classroom composition data are inherently complex. One of the key issues concerns their hierarchical structure, meaning that students are nested in classes (there may be further levels, such as schools or measurement occasions). It is generally assumed that classroom composition research needs to take into account this data structure by applying multilevel analysis (Hox, 2010; Snijders \& Bosker, 2012). Multilevel modeling not only allows accounting for dependencies between students of the same classroom but also provides interesting further analyses of cross-level interactions or multilevel mediation, among others. With its specific focus on the classroom level, in CCRSO, a sufficiently large sample size of classrooms seems to be particularly important (Maas \& Hox, 2005).

As pointed out by Lüdtke et al. (2011), another central problem of compositional analyses is that error-free measurement of constructs cannot be achieved. First, constructs are affected by measurement errors. Second, sampling errors arise from data collection processes. This problem concerns notably reflective aggregation of group-level constructs because this type of aggregation corresponds to an infinite sampling process. Thus, strategies for dealing with unreliability in reflective aggregated group-level constructs such as classroom climate are of 
crucial importance (e.g., Lüdtke et al., 2011; Marsh et al., 2012). Advanced multilevel techniques offer the possibility to correct for measurement errors as well as sampling errors by adopting a structural equation modeling framework, including so-called doubly latent multilevel models (e.g., Marsh et al., 2009) or multilevel latent contextual models (Lüdtke et al., 2011). However, increased sample size is required for such analyses.

Other important methodological considerations in CCRSO are related to questions of the handling of missing data (e.g., Enders, 2010) and the appropriate estimation method to use. Moreover, social-emotional outcomes are often not normally distributed. For example, delinquent acts are rare in typical populations of children and adolescents, and distribution thus is often strongly skewed (e.g., Childs, Sullivan, \& Gulledge, 2011; Müller et al., 2016a). In such cases, it can be advisable to use statistical procedures that specifically allow for modeling of data with skewed distributions (e.g., Berk \& MacDonald, 2008; Coxe, West, \& Aiken, 2009; Hilbe, 2008).

\section{CONCLUDING REMARKS}

In this overview on CCRSO, it has become evident that, based on the two strong research lines of peer influence and school effectiveness research, studies related to CCRSO have the potential to significantly contribute to a better understanding of the social-emotional outcomes of children and adolescents. At the same time, there are still many open questions regarding the relationship between classroom composition and students' social-emotional development. To summarize our view of the current state of research and to describe some future directions, we would thus like to conclude with four brief remarks.

First, studies related to CCRSO provide growing evidence that the composition of classrooms matters for individual students' social-emotional development. The impact of classroom composition thereby appears to be present over and above the well-established influence of self-selected peer groups (although this question needs more inquiry). This may be considered as a general impetus for researchers to pay increased attention to the involuntary peer group of (all) classmates. A specifically important desiderate is, to shed more light on the mediating and moderating processes underlying classroom composition effects on social-emotional outcomes. A better understanding of these processes may have important implications both for theory and school practice.

Second, studies related to CCRSO should aim to consider individual characteristics, classroom peer context, and school environment characteristics together. This relates both to theoretical concepts and to empirical investigation. In this sense, an even more intense exchange between peer influence research and school effectiveness research, in our view, holds much potential to further move forward CCRSO. The promise herein lies in being able to develop more comprehensive models of classroom composition effects that explicitly take into account both the knowledge on proximal peer influence processes and the different levels of school organization (i.e., school system, school, classroom, student). This may allow, for example, to more closely investigate the temporal sequence of processes resulting in classroom composition effects. Different steps may be thought of, such as (a) students are assigned to classrooms based on characteristics of the school system, the local school, and individual students; (b) students select friends in their new classroom based on homophily; and (c) students' social-emotional outcomes are influenced by their friends and other classmates as well as interacting school factors. 
Third, although a lot of progress has been made regarding methodology, there still is much work ahead in terms of most optimal operationalization and methods of analyses of classroom composition effects on social-emotional outcomes. Although a main challenge remains to adequately measure and analyze the central concepts of CCRSO, the past development of composition research brings hope that further advances will be made and new methodological possibilities will also contribute to asking new theoretical questions.

Fourth, based on the accumulating evidence of classroom composition effects on socialemotional outcomes, efforts should be made to develop concepts on the practical implications of CCRSO. Although there are first recommendations for educational practice on how to deal with negative peer influence on antisocial behavior (e.g., Dodge et al., 2006; Müller, 2012), concepts specific to classroom composition effects and relating to different levels of school organization should be developed and undergo systematic empirical investigation.

Having pointed to these future perspectives, we are confident that the seven studies presented in this special issue can significantly contribute to the further development of CCRSO. In fact, many of them relate directly to the questions that are currently most discussed in the field of CCRSO. We heartily thank all the participating authors and reviewers for their valuable contributions. Furthermore, we also want to thank the editor-in-chief of the Journal of Cognitive Education and Psychology, Marco Hessels, for letting us put this work together.

Christoph M. Müller and Carmen L. A. Zurbriggen Guest Editors

\section{REFERENCES}

Abraham, J. (1989). Testing Hargreaves' and Lacey's differentiation-polarisation theory in a setted comprehensive. British Journal of Sociology, 40(1), 46-81.

Akers, R. L. (2009). Social learning and social structure: A general theory of crime and deviance (2nd ed.). New Brunswick, NJ: Transaction.

Akers, R. L., \& Jensen, G. F. (2006). The empirical status of social learning theory of crime and deviance: The past, present, and future. In F. T. Cullen, J. P. Wright, \& K. R. Blevins (Eds.), Taking stock: The status of criminological theory (pp. 37-76). New Brunswick, NJ: Transaction.

Alexander, K., \& Eckland, B. K. (1975). Contextual effects in the high school attainment process. American Sociological Review, 40(3), 402-416.

Algina, J., \& Swaminathan, H. (2011). Centering in two-level nested designs. In J. J. Hox \& J. K. Roberts (Eds.), Handbook of advanced multilevel analysis (pp. 285-312). New York, NY: Routledge.

Araos, C., Cea, M., Fernandez, M., \& Valenzuela, E. (2014). The role of school context on marijuana use in Chile: A classroom-level analysis. Deviant Behavior, 35, 412-432.

Asher, S. R., \& McDonald, K. L. (2009). The behavioral basis of acceptance, rejection, and perceived popularity. In K. H. Rubin, W. M. Bukowski, \& B. Laursen (Eds.), Handbook of peer interactions, relationships, and groups (pp. 232-248). New York, NY: Guilford Press.

Bandura, A. (1977). Social learning theory. Englewood Cliffs, NJ: Prentice-Hall.

Barry, C. M., \& Wentzel, K. R. (2006). Friend influence on prosocial behavior: The role of motivational factors and friendship characteristics. Developmental Psychology, 42, 153-163.

Barth, J. M., Dunlap, S. T., Dane, H., Lochman, J. E., \& Wells, K. C. (2004). Classroom environment influences on aggression, peer relations, and academic focus. Journal of School Psychology, 42, 115-133.

Bellmore, A. D., Witkow, M. R., Graham, S., \& Juvonen, J. (2004). Beyond the individual: The impact of ethnic context and classroom behavioral norms on victims' adjustment. Developmental Psychology, 40, 1159-1172. 
Berends, M. (1995). Educational stratification and students' social bonding to school. British Journal of Sociology of Education, 16(3), 327-351.

Berk, R., \& MacDonald, J. M. (2008). Overdispersion and poisson regression. Journal of Quantitative Criminology, 24(3), 269-284.

Blakely-McClure, S. J., \& Ostrov, J. M. (2016). Relational aggression, victimization and self-concept: Testing pathways from middle childhood to adolescence. Journal of Youth and Adolescence, 45(2), 376-390.

Bliese, P. D. (2000). Within-group agreement, non-independence, and reliability: Implications for data aggregation and analysis. In K. J. Klein \& S. W. J. Koslowski (Eds.), Multilevel theory, research, and methods in organizations: Foundations, extensions, and new directions (pp. 349-381). San Francisco, CA: Jossey-Bass.

Bosse, T., Gerritsen, C., \& Klein, M. C. A. (2010). Predicting the development of juvenile delinquency by simulation. In N. García-Pedrajas, F. Herrera, C. Fyfe, J. M. Benítez, \& M. Ali (Eds.), Trends in applied intelligent systems: Proceedings of the 23rd international conference on industrial engineering and other applications of applied intelligent systems, IEA/AIE 2010 Cordoba, Spain, June 1-4, 2010 proceedings, Part II (pp. 565-574). Berlin, Germany: Springer.

Brooks-Gunn, J., Duncan, G. J., \& Aber, J. L. (Eds.). (2000). Neighborhood poverty: Context and consequences for children. New York, NY: Russel Sage Foundation.

Brown, B. B., Bakken, J. P., Ameringer, S. W., \& Mahon, S. D. (2008). A comprehensive conceptualization of the peer influence process in adolescence. In M. J. Prinstein \& K. A. Dodge (Eds.), Understanding peer influence in children and adolescents (pp. 17-44). New York, NY: Guilford Press.

Brutsaert, H., \& Van Houtte, M. (2004). Gender context of schooling and levels of stress among early adolescent pupils. Education and Urban Society, 37, 58-73.

Burgess, R. L., \& Akers, R. L. (1966). A differential association-reinforcement theory of criminal behavior. Social Problems, 14, 128-147.

Burns, R. B., \& Mason, D. A. (2002). Class composition and student achievement in elementary schools. American Educational Research Journal, 39(1), 207-233.

Busching, R., \& Krahé, B. (2015). The girls set the tone: Gendered classroom norms and the development of aggression in adolescence. Personality \& Social Psychology Bulletin, 41, 659-676.

Buyse, E., Verschueren, K., Doumen, S., Van Damme, J., \& Maes, F. (2008). Classroom problem behavior and teacher-child relationships in kindergarten: The moderating role of classroom climate. Journal of School Psychology, 46, 367-391.

Castellano, K. E., Rabe-Hesketh, S., \& Skrondal, A. (2014). Composition, context, and endogeneity in school and teacher comparisons. Journal of Educational and Behavioral Statistics, 39(5), 333-367.

Chang, L. (2004). The role of classroom norms in contextualizing the relations of children`s social behaviors to peer acceptance. Developmental Psychology, 40, 691-702.

Chapman, C., Armstrong, P., Harris, A., Muijs, D., Reynolds, D., \& Sammons, P. (2012). School effectiveness and improvement research, policy and practice: Challenging the orthodoxy? New York, NY: Routledge.

Childs, K. K., Sullivan, C. J., \& Gulledge, L. M. (2011). Delinquent behavior across adolescence: Investigating the shifting salience of key criminological predictors. Deviant Behavior, 32, 64-100.

Chmielewski, A. K., Dumont, H., \& Trautwein, U. (2013). Tracking effects depend on tracking type: An international comparison of students' mathematics self-concept. American Educational Research Journal, 50(5), 925-957.

Cialdini, R. B., Borden, R. J., Thorne, A., Walker, M. R., Freeman, S., \& Sloan, L. R. (1976). Basking in reflected glory. Three (football) field studies. Journal of Personality and Social Psychology, 34(3), 366-375.

Cialdini, R. B., Kallgren, C. A., \& Reno, R. R. (1991). A focus theory of normative conduct. Advances in Experimental Social Psychology, 24, 201-234. 
Ciarrochi, J., Scott, G., Deane, F. P., \& Heaven, P. C. L. (2003). Relations between social and emotional competence and mental health: A construct validation study. Personality and Individual Differences, 35, 1947-1963.

Cillessen, A., \& Marks, P. E. L. (2011). Conceptualizing and measuring popularity. In A. Cillessen, D. Schwartz, \& L. Mayeux (Eds.), Popularity in the peer system (pp. 25-56). New York, NY: Guilford Press.

Coleman, J. S., Campell, E. Q., Hobson, C. J., McPartland, J., Mood, A. M., Weinfeld, F. D., \& York, R. L. (1966). Equality of educational opportunity. Washington, DC: U.S. Government Printing Office.

Coxe, S., West, S. G., \& Aiken, L. S. (2009). The analysis of count data: A gentle introduction to poisson regression and its alternatives. Journal of Personality Assessment, 91(2), 121-136.

Cronbach, L. J. (1976). Research on classroom and schools: Formulation of questions, design, and analysis. Stanford, CA: Stanford Evaluation Consortium.

Crosnoe, R. (2011). Fitting in, standing out: Navigating the social challenges of high school to get an education. New York, NY: Cambridge University Press.

Davis, J. A. (1966). The campus as a frog pond: An application of the theory of relative deprivation to career decisions of college men. American Journal of Sociology, 72(1), 17-31.

Demanet, J., \& Van Houtte, M. (2011). Social-ethnic school composition and school misconduct: Does sense of futility clarify the picture? Sociological Spectrum, 31, 224-256.

Denham, S. A., Wyatt, T. M., Bassett, H. H., Echeverria, D., \& Knox, S. S. (2009). Assessing socialemotional development in children from a longitudinal perspective. Journal of Epidemiology and Community Health, 63, i37-i52.

Deutsch, M., \& Gerard, H. B. (1955). A study of normative and informational social influences upon individual judgement. Journal of Abnormal and Social Psychology, 51, 629-636.

Dishion, T. J., \& Piehler, T. F. (2009). Deviant by design: Peer contagion in development, interventions, and schools. In K. H. Rubin, W. M. Bukowski, \& B. Laursen (Eds.), Handbook of peer interactions, relationships, and groups (pp. 589-602). New York, NY: Guilford Press.

Dishion, T. J., Spracklen, K. M., Andrews, D. W., \& Patterson, G. R. (1996). Deviancy training in male adolescent friendships. Behavior Therapy, 27, 373-390.

Dishion, T. J., \& Tipsord, J. M. (2011). Peer contagion in child and adolescent social and emotional development. Annual Review of Psychology, 62, 189-214.

Dodge, K. A., Dishion, T. J., \& Lansford, J. E. (Eds.). (2006). Deviant peer influences in programs for youth. New York, NY: Guilford Press.

Dreeben, R., \& Barr, R. (1988). Classroom composition and the design of instruction. Sociology of Education, 61(3), 129-142.

Dumont, H., Neumann, M., Maaz, K., \& Trautwein, U. (2013). Die Zusammensetzung der Schülerschaft als Einflussfaktor für Schulleistungen: Internationale und nationale Befunde [The effect of student body composition on academic achievement: International and national evidence]. Psychologie in Erziehung und Unterricht, 60, 163-183.

Enders, C. K. (2010). Applied missing data analysis. New York, NY: Guilford Press.

Enders, C. K., \& Tofighi, D. (2007). Centering predictor variables in cross-sectional multilevel models: A new look at an old issue. Psychological Methods, 12(2), 121-138.

Erbring, L., \& Young, A. A. (1979). Individuals and social structure: Contextual effects as endogenous feedback. Sociological Methods \& Research, 7, 396-430.

Farmer, T. W., Lines, M., \& Hamm, J. V. (2011). Revealing the invisible hand: The role of teachers in children's peer experiences. Journal of Applied Developmental Psychology, 32, 247-256.

Gamoran, A. (1987). The stratification of high school learning opportunities. Sociology of Education, 60(3), 135-155.

Gamoran, A. (2010). Tracking and inequality: New directions for research and practice. In M. W. Apple, S. J. Ball, \& L. A. Gandin (Eds.), The Routledge international handbook of the sociology of education (pp. 213-228). New York, NY: Routledge. 
Garcia, R. L., Meagher, B. R., \& Kenny, D. A. (2015). Analyzing the effects of group members' characteristics: A guide to the group actor-partner interdependence model. Group Processes \& Intergroup Relations, 18(3), 315-328.

Gaylord, M. S., \& Galliher, J. F. (1988). The criminology of Edwin Sutherland. New Brunswick, NJ: Transaction.

Gottfredson, D. (2001). Schools and delinquency. Cambridge, United Kingdom: Cambridge University Press.

Hallinan, M. T. (1988). School composition and learning: A critique of the Dreeben-Barr model. Sociology of Education, 61(3), 143-146.

Hanushek, E. A., \& Woessmann, L. (2006). Does educational tracking affect performance and inequality? Differences-in-differences evidence across countries. The Economic Journal, 116, C63-C76.

Hargreaves, D. H. (1967). Social relations in a secondary school. London, United Kingdom: Routledge and Kenan Paul.

Harker, R., \& Tymms, P. (2004). The effects of student composition on school outcomes. School Effectiveness and School Improvement, 15(2), 177-199.

Hartup, W. W. (2009). Critical issues and theoretical viewpoints. In K. H. Rubin, W. M. Bukowski, \& B. Laursen (Eds.), Handbook of peer interactions, relationships, and groups (pp. 3-19). New York, NY: Guilford Press.

Henry, D., Guerra, N., Huesmann, R., Tolan, P., VanAcker, R., \& Eron, L. (2000). Normative influences on aggression in urban elementary school classrooms. American Journal of Community Psychology, 28, 59-81.

Hilbe, J. M. (2008). Negative binomial regression. Cambridge, United Kingdom: Cambridge University Press. Hoglund, W. L., \& Leadbeater, B. J. (2004). The effects of family, school, and classroom ecologies on changes in children's social competence and emotional and behavioral problems in first grade. Developmental Psychology, 40, 533-544.

Hogue, A., \& Steinberg, L. (1995). Homophily of internalized distress in adolescent peer groups. Developmental Psychology, 31, 897-906.

Hornstra, L., van der Veen, I., Peetsma, T., \& Volman, M. (2015). Does classroom composition make a difference: Effects on developments in motivation, sense of classroom belonging, and achievement in upper primary school. School Effectiveness and School Improvement, 26(2), 125-152. http://dx.doi .org/10.1080/09243453.2014.887024

Hox, J. J. (2010). Multilevel analysis: Techniques and applications (2nd ed.). New York, NY: Routledge.

Huguet, P., Dumas, F., Marsh, H., Wheeler, L., Seaton, M., Nezlek, J., . . Régner, I. (2009). Clarifying the role of social comparison in the big-fish-little-pond effect (BFLPE): An integrative study. Journal of Personality and Social Psychology, 97(1), 156-170.

Jackson, D. R., Cappella, E., \& Neal, J. W. (2015). Aggression norms in the classroom social network: Contexts of aggressive behavior and social preference in middle childhood. American Journal of Community Psychology, 56, 293-306.

Jackson, M. F., Barth, J. M., Powell, N., \& Lochman, J. E. (2006). Classroom contextual effects of race on children's peer nominations. Child Development, 77, 1325-1337.

Jencks, C., Smith, M., Acland, H., Bane, M. J., Cohen, D., Gintis, H., .. Michelson, S. (1972). Inequality: A reassessment of the effect of family and schooling in America. New York, NY: Basic Books.

Jonkmann, K., Trautwein, U., \& Lüdtke, O. (2009). Social dominance in adolescence: The moderating role of the classroom context and behavioral heterogeneity. Child Development, 80, 338-355.

Juvonen, J., \& Galván, A. (2008). Peer influence in involuntary social groups. Lessons from research on bullying. In M. J. Prinstein \& K. A. Dodge (Eds.), Understanding peer influence in children and adolescents (pp. 225-244). New York, NY: Guilford Press.

Kellam, S. G., Ling, X., Merisca, R., Brown, C. H., \& Ialongo, N. (1998). The effect of the level of aggression in the first grade classroom on the course of malleability of aggressive behavior into middle school. Development and Psychopathology, 10, 165-185. 
Kenny, D. A., \& Garcia, R. L. (2012). Using the actor-partner interdependence model to study the effects of group composition. Small Group Research, 43(4), 468-496.

Kerckhoff, A. C. (2001). Education and social stratification processes in comparative perspective. Sociology of Education, 74, 3-18.

Kessler, R. C., McLaughlin, K. A., Green, J. G., Gruber, M. J., Sampson, N. A., Zaslavsky, A. M., . . . Williams, D. R. (2010). Childhood adversities and adult psychopathology in the WHO World Mental Health Surveys. The British Journal of Psychiatry, 197, 378-385.

Kiesner, J., Poulin, F., \& Nicotra, E. (2003). Peer relations across contexts: Individual-network homophily and network inclusion in and after school. Child Development, 74, 1328-1343.

Kindermann, T., \& Gest, S. (2009). Assessment of the peer group: Identifying naturally occurring social networks and capturing their effects. In K. H. Rubin, W. M. Bukowski, \& B. Laursen (Eds.), Handbook of peer interactions, relationships, and groups (pp. 100-117). New York, NY: Guilford Press.

Kuppens, S., Grietens, H., Onghena, P., Michiels, D., \& Subramanian, S. V. (2008). Individual and classroom variables associated with relational aggression in elementary-school aged children: A multilevel analysis. Journal of School Psychology, 46, 639-660.

Little, T. D., Bovaird, J. A., \& Card, N. A. (2007). Modeling contextual effects in longitudinal studies. Mahwah, NJ: Lawrence Erlbaum Associates.

Lüdtke, O., Marsh, H. W., Robitzsch, A., \& Trautwein, U. (2011). A $2 \times 2$ taxonomy of multilevel latent contextual models: Accuracy-bias trade-offs in full and partial error correction models. Psychological Methods, 16(4), 444-467.

Lüdtke, O., Marsh, H. W., Robitzsch, A., Trautwein, U., Asparouhov, T., \& Muthén, B. (2008). The multilevel latent covariate model: A new, more reliable approach to group-level effects in contextual studies. Psychological Methods, 13(3), 203-229.

Lüdtke, O., Robitzsch, A., Trautwein, U., \& Kunter, M. (2009). Assessing the impact of learning environments: How to use student ratings of classroom or school characteristics in multilevel modeling. Contemporary Educational Psychology, 34, 120-131.

Maas, C. J. M., \& Hox, J. J. (2005). Sufficient sample sizes for multilevel modeling. Methodology, 1(3), 86-92.

Maaz, K., Trautwein, U., Lüdtke, O., \& Baumert, J. (2008). Educational transitions and differential learning environments: How explicit between-school tracking contributes to social inequality in educational outcomes. Child Development Perspectives, 2(2), 99-106.

MacKinnon, D. P. (2008). Introduction to statistical mediation analysis. New York, NY: Lawrence Erlbaum Associates.

Manski, C. F. (1993). Identification of endogenous social effects: The reflection problem. The Review of Economic Studies, 60, 531-542.

Marsh, H. W. (1987). The big-fish-little-pond effect on academic self-concept. Journal of Educational Psychology, 79(3), 280-295. http://dx.doi.org/10.1024/1010-0652.19.3.119

Marsh, H. W., Kong, C. K., \& Hau, K. T. (2000). Longitudinal multilevel models of the big-fish-littlepond effect on academic self-concept: Counterbalancing contrast and reflected-glory effects in Hong Kong schools. Journal of Personality and Social Psychology, 78(2), 337-349.

Marsh, H. W., Lüdtke, O., Nagengast, B., Trautwein, U., Morin, A. J. S., Abduljabbar, A. S., \& Köller, O. (2012). Classroom climate and contextual effects: Conceptual and methodological issues in the evaluation of group-level effects. Educational Psychologist, 47, 106-124.

Marsh, H. W., Lüdtke, O., Robitzsch, A., Trautwein, U., Asparouhov, T., Muthén, B., \& Nagengast, B. (2009). Doubly-latent models of school contextual effects: Integrating multilevel and structural equation approaches to control measurement and sampling error. Multivariate Behavioral Research, 44, 764-802.

Masten, A. S., \& Coatsworth, J. D. (1998). The development of competence in favorable and unfavorable environments: Lessons from research on successful children. American Psychologist, 53, 205-220. 
Mercer, S. H., McMillen, J. S., \& DeRosier, M. E. (2009). Predicting change in children's aggression and victimization using classroom-level descriptive norms of aggression and pro-social behavior. Journal of School Psychology, 47, 267-289.

Morris, A. S., Silk, J. S., Steinberg, L., Myers, S. S., \& Robinson, L. R. (2007). The role of the family context in the development of emotion regulation. Social Development, 16, 361-388.

Müller, C. (2010). Negative peer influence in special needs classes-A risk for students with problem behaviour? European Journal of Special Needs Education, 25, 431-444.

Müller, C. (2012). Avoiding negative peer influence on problem behaviors. What can schools do? Zeitschrift für Heilpädagogik, 64, 452-460.

Müller, C., \& Hofmann, V. (2014). Does being assigned to a low school track negatively affect psychological adjustment? A longitudinal study in the first year of secondary school. School Effectiveness and School Improvement, 27(2), 95-115. http://dx.doi.org/10.1080/09243453.2014.980277

Müller, C., Hofmann, V., \& Arm, S. (in press). Susceptibility to classmates' influence on delinquency during early adolescence. Journal of Early Adolescence.

Müller, C., Hofmann, V., Fleischli, J., \& Studer, F. (2016a). Effects of classroom composition on the development of antisocial behavior in lower secondary school. Journal of Research on Adolescence, 26(2), 345-359.

Müller, C., Hofmann, V., Fleischli, J., \& Studer, F. (2015). “Tell me what your classmates do and I will tell you what you are going to do?" The influence of classroom composition on the development of problem behavior in school. Zeitschrift für Erziehungswissenschaft, 18, 569-589.

Müller, C., Hofmann, V., Fleischli, J., \& Studer, F. (2016b). Classroom peer influence from the entire class, dominant students, and friends. Journal of Cognitive Education and Psychology, 15, $122-145$.

Müller, C., \& Minger, M. (2013). Which children and adolescents are most susceptible to peer influence? A systematic review regarding antisocial behavior. Empirische Sonderpädagogik, 2, 107-129.

Oakes, J. (1987). Tracking in secondary schools: A contextual perspective. Educational Psychologist, 22(2), 129-153.

Paccagnella, O. (2006). Centering or not centering in multilevel models? The role of group mean and the assessment of group effects. Evaluation Review, 30, 66-85.

Pas, E. T., Cash, A. H., O’Brennan, L., Debnam, K. J., \& Bradshaw, C. P. (2015). Profiles of classroom behavior in high schools: Associations with teacher behavior management strategies and classroom composition. Journal of School Psychology, 53, 137-148.

Powers, C. J., \& Bierman, K., L. (2013). The multifaceted impact of peer relations on aggressivedisruptive behavior in early elementary school. Developmental Psychology, 49, 1174-1186.

Prinstein, M. J. (2007). Moderators of peer contagion: A longitudinal examination of depression socialization between adolescents and their best friends. Journal of Clinical Child and Adolescent Psychology, 36, 159-170.

Prinstein, M. J., \& Dodge, K. A. (Eds.). (2008). Understanding peer influence in children and adolescents. New York, NY: Guilford Press.

Raine, A. (2008). From genes to brain to antisocial behavior. Current Directions in Psychological Science, 17, 323-328.

Rambaran, A. J., Dijkstra, J. K., \& Stark, T. H. (2013). Status-based influence processes: The role of norm salience in contagion of adolescent risk attitudes. Journal of Research on Adolescence, 23, 574-585.

Raudenbush, S., \& Bryk, A. S. (1986). A hierarchical model for studying school effects. Sociology of Education, 59(1), 1-17.

Reinke, W. M., \& Walker, H. M. (2006). Deviant peer effects in education. In K. A. Dodge, T. J. Dishion, \& J. E. Lansford (Eds.), Deviant peer influences in programs for youth (pp. 122-140). New York, NY: Guilford Press.

Rubin, K. H., Bukowski, W. M., \& Laursen, B. (Eds.). (2009). Handbook of peer interactions, relationships, and groups. New York, NY: Guilford Press. 
Rutter, M., Kim-Cohen, J., \& Maughan, B. (2006). Continuities and discontinuities in psychopathology between childhood and adult life. Journal of Child Psychology and Psychiatry, 47, 276-295.

Rutter, M., Maughan, B., Mortimore, P., \& Ouston, J. (1979). Fifteen thousand hours: Secondary schools and their effects on children. Somerset, United Kingdom: Open Books.

Scheerens, J., \& Creemers, B. P. M. (1989). Conceptualizing school effectiveness. International Journal of Educational Research, 13(7), 691-706.

Seaton, M., Marsh, H. W., \& Craven, R. G. (2009). Earning its place as a pan-human theory. Universality of the big-fish-little-pond effect across 41 culturally and economically diverse countries. Journal of Educational Psychology, 101(2), 403-419.

Skinner, E. A., \& Belmont, M. J. (1993). Motivation in the classroom: Reciprocal effects of teacher behavior and student engagement across the school year. Journal of Educational Psychology, 85, 571-581.

Snijders, T. A. B., \& Bosker, R. J. (2012). Multilevel analysis: An introduction to basic and advanced multilevel modeling (2nd ed.). London, United Kingdom: Sage.

Stearns, E., Dodge, K. A., \& Nicholson, M. (2008). Peer contextual influences on the growth of authorityacceptance problems in early elementary school. Merrill Palmer Quarterly, 54, 208-231.

Stormshak, E. A., Bierman, K. L., Bruschi, C., Dodge, K. A., \& Coie, J. D. (1999). The relation between behavior problems and peer preference in different classroom contexts. Child Development, 70, 169-182.

Teddlie, C., \& Reynolds, D. (2000). The international handbook of school effectiveness research. London, United Kingdom: Falmer Press.

Thomas, D. E., \& Bierman, K. L. (2006). The impact of classroom aggression on the development of aggressive behavior problems in children. Development and Psychopathology, 18, 471-487.

Thomas, D. E., Bierman, K. L., \& Powers, C. J. (2011). The influence of classroom aggression and classroom climate on aggressive-disruptive behavior. Child Development, 82, 751-757.

Trautwein, U., Lüdtke, O., Marsh, H. W., \& Nagy, G. (2009). Within-school social comparison: How students perceive the standing of their class predicts academic self-concept. Journal of Educational Psychology, 101(4), 853-866.

Van den Berg, Y. H. M., Segers, E., \& Cillessen, A. H. N. (2012). Changing peer perceptions and victimization through classroom arrangements: A field experiment. Journal of Abnormal Child Psychology, 40, 403-412.

Van Ewijk, R., \& Sleegers, P. (2010a). Peer ethnicity and achievement: A meta-analysis into the compositional effect. School Effectiveness and School Improvement, 21(3), 237-265.

Van Ewijk, R., \& Sleegers, P. (2010b). The effect of peer socioeconomic status on student achievement: A meta-analysis. Educational Research Review, 5, 134-150.

Van Houtte, M. (2004). Tracking effects on school achievement: A quantitative explanation in terms of the academic culture of school staff. American Journal of Education, 110, 354-388.

Van Houtte, M. (2006). School type and academic culture: Evidence for the differentiation-polarization theory. Journal of Curriculum Studies, 38, 273-292.

Van Houtte, M., \& Stevens, P. A. J. (2008). Sense of futility: The missing link between track position and self-reported school misconduct. Youth \& Society, 40(2), 245-264.

Vitaro, F., Brendgen, M., \& Tremblay, R. E. (2000). Influence of deviant friends on delinquency: Searching for moderator variables. Journal of Abnormal Child Psychology, 28, 313-325.

Vogl, K., \& Preckel, F. (2014). Full-time ability grouping of gifted students: Impact on social self-concept and school-related attitudes. Gifted Child Quarterly, 58(1), 51-68.

Warr, M. (2002). Companions in crime: The social aspects of criminal conduct. Cambridge, United Kingdom: Cambridge University Press.

Warren, K., Schoppelrey, S., Moberg, P., \& McDonald, M. (2005). A model of contagion through competition in the aggressive behaviors of elementary school students. Journal of Abnormal Child Psychology, 33, 283-292. 
Weissberg, R. P., Durlak, J. A., Domitrovich, C. E., \& Gullotta, T. P. (2015). Social and emotional learning: Past, present, and future. In J. A. Durlak, C. E. Domitrovich, R. P. Weissberg, \& T. P. Gullotta (Eds.), Handbook of social and emotional learning: Research and practice (pp. 3-19). New York, NY: Guilford Press.

Werthamer-Larsson, L., Kellam, S., \& Wheeler, L. (1991). Effects of first grade classroom environment on shy behavior, aggressive behavior, and concentration problems. American Journal of Community Psychology, 19, 585-602.

Wilkinson, I. A. G., Parr, J. M., Fung, I. Y. Y., Hattie, J. A. C., \& Townsend, M. A. R. (2002). Discussion: modeling and maximizing peer effects in school. International Journal of Educational Research, 37, 521-535.

Wright, J. C., Giammarino, M., \& Parad, H. W. (1986). Social status in small groups: Individual-group similarity and the social "misfit." Journal of Personality and Social Psychology, 50, 523-536.

Yudron, M., Jones, S. M., \& Raver, C. C. (2014). Implications of different methods for specifying classroom composition of externalizing behavior and its relationship to social-emotional outcomes. Early Childhood Research Quarterly, 29, 682-691.

Zurbriggen, C. (2016). Schulklasseneffekte: Schülerinnen und schüler zwischen komparativen und normativen einflüssen [Effects of the school class: Students between comparative and normative influences]. Wiesbaden, Germany: Springer.

Correspondence regarding this article should be directed to Christoph M. Müller, Department of Special Education, University of Fribourg, Petrus-Kanisius-Gasse 21, 1700 Fribourg, Switzerland. E-mail: christoph.mueller2@unifr.ch 